\title{
Transport coefficients for low and high-rate mass transfer along a biological horizontal cylinder
}

\author{
Alberto A. Barreto ${ }^{1}$, Mauri Fortes ${ }^{2}$, Wanyr R. Ferreira ${ }^{2} \&$ Luiz C. A. Crespo $^{3}$
}

\begin{abstract}
Knowledge of heat and mass transfer coefficients is essential for drying simulation studies or design of food and grain thermal processes, including drying. This work presents the full development of a segregated finite element method to solve convection-diffusion problems. The developed scheme allows solving the incompressible, steady-state Navier-Stokes equations and convective-diffusive problems with temperature and moisture dependent properties. The problem of simultaneous energy, momentum and species transfer along an infinite, horizontal cylinder under drying conditions in forced convection is presented, considering conditions normally found in biological material thermal treatment or drying. Numerical results for Nusselt and Sherwood numbers were compared against available empirical expressions; the results agreed within the associated experimental errors. For high rate mass transport processes, the proposed methodology allows to simulate drying conditions involving wall convective mass flux by a simple inclusion of the appropriated boundary conditions.
\end{abstract}

Key words: drying, heat transfer, convection, diffusion

\section{Coeficientes de transporte para baixas e altas taxas de transferência de massa ao longo de um cilindro biológico horizontal}

\section{RESUMO}

O conhecimento dos coeficientes de transferência de calor e massa é essencial para o estudo de simulação de secagem e para o projeto de processamento térmico de grãos e alimentos, inclusive secagem. Este trabalho apresenta o desenvolvimento completo de um método de elementos finitos segregado para resolver problemas de convecção-difusão. O esquema desenvolvido permite que se resolvam as equações de Navier-Stokes incompressíveis em regime permanente, além de problemas convectivos-difusivos com propriedades dependentes da temperatura e da umidade. Apresenta-se o problema de transferência simultânea de energia, momentum e espécies ao longo de um cilindro horizontal, infinito sob condições de secagem em convecção forçada, considerando-se condições normalmente encontradas em tratamento térmico ou secagem de material biológico. Compararam-se resultados numéricos para Nusselt e Sherwood com expressões empíricas disponíveis; os resultados concordaram dentro dos erros experimentais associados. Para processos com altas taxas de transporte de massa, a metodologia proposta permite simular condições de secagem envolvendo fluxo convectivo de massa na parede, por meio de uma simples inclusão de condições de contorno apropriadas.

Palavras-chave: secagem, transferência de calor, convecção, difusão

${ }^{1}$ CDTN - National Council of Nuclear Energy. Av. Antônio Carlos, 6627, CEP 31270-901, Belo Horizonte, MG. Phone: (31) 3499-3247. E-mail: aab@urano.cdtn.br ${ }^{2}$ Centro Universitário UNA. R. José Cláudio Resende, 80, CEP 30455-590, Belo Horizonte, MG. Phone: (31) 3379-1220. E-mail: mauri.fortes@ pesquisador.cnpq.br; wanyr@pesquisador.cnpq.br

${ }^{3}$ DEMEC/UFMG. Av. Antônio Carlos, 6627, CEP 31270-901, Belo Horizonte, MG. Phone: (31) 3641-4007. E-mail: luizcrespo@engefril.com.br 


\section{INTRODUCTION}

Drying is a unit operation present in several biological and industrial processes such as drying of agricultural products, food dehydration, wood thermal treatment, drying of ceramics and brick, and also in the study of moisture migration in porous media (Keey, 1972; Fortes \& Okos, 1980; Brooker et al., 1992). In the last decades, many researches related to food and grain drying and heat treatment have been carried on to obtain the required physical and thermal properties required for proper drier or process design (Churchill, 1977; Zahed \& Epstein, 1992, 1993; Muthu \& Chattopadhyay, 1993; de Ville \& Smith, 1996; Galan-Domingo \& Martinez-Vera, 1996; Smith, 1996; Sotocinal et al., 1997; Tolaba et al., 1997).

Drying analysis involves heat and mass transfer conjugate processes, both in the solid and in the fluid. Sophisticated models for drying have been formulated either by means of classical (mechanistic) theories (Phillip \& de Vries, 1957), or non-equilibrium thermodynamic (Luikov, 1966). Flux equations based on both irreversible thermodynamics and mechanistic theories can also be applied to grain drying (Fortes \& Okos, 1981).

A complete modeling of drying problems by means of any theory involves a set of non-linear diffusion equations as applied to the drying medium, coupled to the respective boundary layer equations. Numerical (finite difference, FDM, finite volume, FVM, and finite element methods, FEM) and analytical methods have been used for discretizing and, thus, solving convective-diffusive partial differential equations. The literature related to the FEM (Zienkiewicz \& Taylor, 1989, 1991; Fortes, 1997; Fang et al., 1997; Carey et al., 1998; Fortes \& Ferreira, 1999; Baker et al., 1999), FVM (Patankar, 1980; Versteeg \& Malalasekera, 1995; Moukalled \& Darwish, 1997) and FDM (Patel et al., 1985; Hirsch, 1988; Hoffman, 1992; Balzano, 1999; Sengupta \& Nair, 1999) used to solve convection-diffusion problems is abundant, and no intent is made here to cover the latest developments.

This paper is concerned with FEM as applied to solving drying-related boundary layer problems; the choice of this method is related to the simplicity of its application when complex geometries are to be considered. The FEM, using Galerkin's formulation, has been used to solve Navier-Stokes' equations. However, Galerkin's method requires the use of direct solvers of the resulting discretized equations, the use of distinct interpolation functions for velocities and pressure and it usually leads to numerical errors due to false diffusion and numerical dispersion (Taylor \& Hughes, 1981; Brooks \& Hughes, 1982).

A comprehensive review of Petrov-Galerkin and TaylorGalerkin FEM is found in Zienkiewicz \& Taylor $(1989,1991)$ and, thus, from the vast literature, only those works directly related to the present paper will be considered here. Hughes (1978) presented a streamline upwind methodology for solving convective-diffusive equations. The method, which led to exact one-dimensional solutions, consisted in applying Galerkin's method to the diffusive terms and a special integration method to the advective terms. Brooks \& Hughes
(1982) developed a finite element formulation for convection-dominated flows utilizing a Petrov-Galerkin's formulation and extending Hughes' methodology (Hughes, 1978), so as to decrease false diffusion effects. Schnipke \& Rice $(1985 a, b)$ presented a finite element method that makes use of upwind values to predict streamlined downwind advection terms; the method employs the same interpolation function for velocities and pressure and allows the use of a segregated method such as the SIMPLE method (Patankar, 1980). However, Schnipke \& Rice's method (Schnipke \& Rice, 1985a,b) is accurate only for convection-dominated flows (Gurgel \& Fortes, 1994). On the other hand, Shaw (1991) also followed a strategy similar to the FVM (Patankar, 1980), and developed a Poisson-type equation for the continuity (pressure) equation, which did not lead to spurious pressure modes. In this way, Shaw's method (Shaw, 1991) also allows using interpolation functions of the same order for velocities and pressure and iterative methods of solution of the discretized equations. However, Shaw's method is limited to problems where Reynolds number are smaller than 5. To overcome the limitation of his method, Shaw (1991) suggested the use of upwind schemes.

This paper is related to obtaining, via solution of the Navier-Stokes equations, expressions for heat and mass transfer coefficients applicable to modeling heat treatment of biological products.

The specific objectives of this work were:

a. To evaluate the predictive ability of the method proposed by Shaw (1991) to solve heat, mass and momentum simultaneous transfer problems in laminar forced convection, for eventual application to drying problems;

b. To obtain, via FEM, heat and mass transfer coefficients, for forced convection across horizontal cylinders, in the Reynolds numbers range between 20 and 100;

c. To analyze the effect of temperature and concentration dependent properties over heat and mass transfer coefficients; and

d. To compare numerical results with available experimental data.

\section{MATERIAL AND METHODS}

\section{Modified FEM for continuity and momentum equations}

In this work, the problem of fluid flow around a horizontal infinite cylinder is studied. The analysis involved the problems of low Reynolds number flow under high and low rate mass transfer with simultaneous heat, mass and momentum transfer. The cylinder is assumed to be in contact with the ambient air and the temperature and concentration $\left(\mathrm{T}_{\infty}\right.$ and $\left.\mathrm{C}_{\infty}\right)$ far from the boundary are fixed, as illustrated in Figure 1:

Continuity, momentum and property equations for this two-dimensional, steady and incompressible flow are

$$
\frac{\partial u}{\partial x}+\frac{\partial v}{\partial y}=0
$$




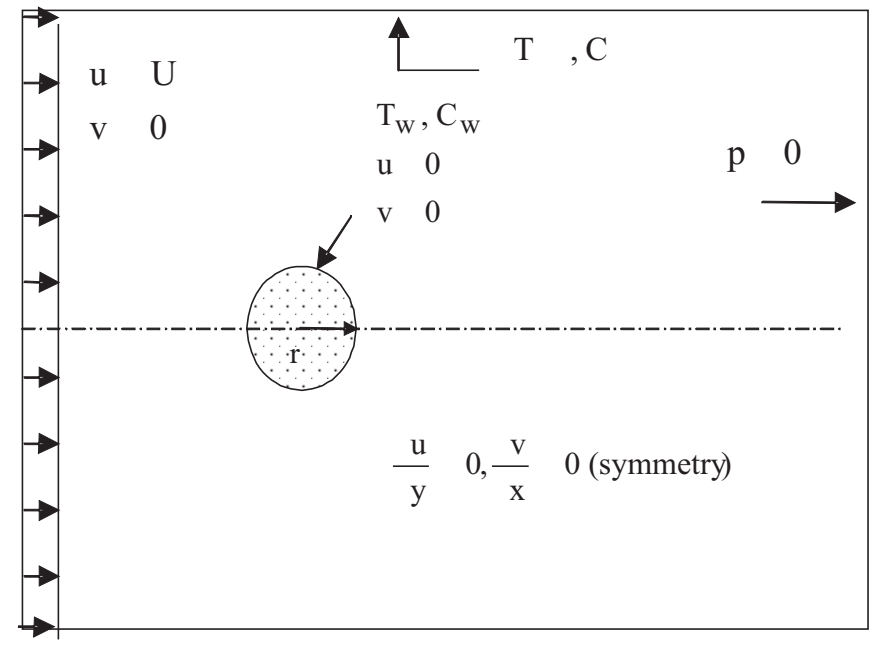

Figure 1. Geometry of an incompressible flow around a horizontal cylinder and associated boundary conditions

$$
\begin{gathered}
\rho u \frac{\partial u}{\partial x}+\rho v \frac{\partial u}{\partial y}=-\frac{\partial p}{\partial x}+\left(\rho_{\infty}-\rho\right)+\frac{\partial}{\partial x}\left(\mu \frac{\partial u}{\partial x}\right)+\frac{\partial}{\partial y}\left(\mu \frac{\partial u}{\partial y}\right) \\
\rho u \frac{\partial v}{\partial x}+\rho v \frac{\partial v}{\partial y}=-\frac{\partial p}{\partial y}+\frac{\partial}{\partial x}\left(\mu \frac{\partial v}{\partial x}\right)+\frac{\partial}{\partial y}\left(\mu \frac{\partial v}{\partial y}\right) \\
\rho c_{p}\left(u \frac{\partial T}{\partial x}+v \frac{\partial T}{\partial y}\right)=\left(\frac{\partial}{\partial x} k \frac{\partial T}{\partial x}+\frac{\partial}{\partial y} k \frac{\partial T}{\partial y}\right) \\
\rho\left(u \frac{\partial C}{\partial x}+v \frac{\partial C}{\partial y}\right)=\left(\frac{\partial}{\partial x} D \frac{\partial C}{\partial x}+\frac{\partial}{\partial y} D \frac{\partial C}{\partial y}\right)
\end{gathered}
$$

The associated boundary conditions are:

$$
\begin{array}{ll}
\text { - at } \mathrm{x}=0 & \mathrm{u}=\mathrm{U}_{\infty}, \mathrm{v}=0, \mathrm{~T}=\mathrm{T}_{\infty}, \mathrm{C}=\mathrm{C}_{\infty} \\
\text { - at } \mathrm{x}=\mathrm{x}_{\max } & \partial \mathrm{u} / \partial \mathrm{x}=\partial \mathrm{v} / \partial \mathrm{x}=\partial \mathrm{T} / \partial \mathrm{x}=\partial \mathrm{C} / \partial \mathrm{x}=0 \\
\text { - at } \mathrm{y}=0 & \partial \mathrm{u} / \partial \mathrm{y}=\partial \mathrm{v} / \partial \mathrm{y}=\partial \mathrm{T} / \partial \mathrm{y}=\partial \mathrm{C} / \partial \mathrm{y}=0 \\
\text { - at } \mathrm{y}=\mathrm{y}_{\max } & \mathrm{u}=\mathrm{U}_{\infty}, \mathrm{v}=0, \mathrm{~T}=\mathrm{T}_{\infty}, \mathrm{C}=\mathrm{C}_{\infty}, \mathrm{p}=0 ;
\end{array}
$$$$
\text { - at the solid wall } \mathrm{u}=0, \mathrm{v}=0, \mathrm{~T}=\mathrm{T}_{\mathrm{w}}, \mathrm{C}=\mathrm{C}_{\mathrm{w}} \text {. }
$$

In the above expressions, $\mathrm{u}$ and $\mathrm{v}$ are velocity components in the $\mathrm{x}$ and $\mathrm{y}$ directions, respectively; $\mathrm{p}$ is the pressure component; $\rho$, the fluid density and $\rho_{\infty}$, its ambient value; $\mu$ and $\mathrm{c}_{\mathrm{p}}$, the fluid dynamic viscosity and specific enthalpy, respectively; $\mathrm{C}$ and $\mathrm{T}$ refer to fluid solute concentration ( $\mathrm{kg}$ vapor $\mathrm{kg}^{-1}$ dry air) and temperature, respectively; $\mathrm{y}_{\max }$ refers to a y-coordinate where the fluid is (approximately) not affected by the presence of the cylinder.

One should note that, in the x-momentum equation, if $\left(\rho_{\infty}-\rho\right) g$ is neglected, the problem reduces to pure forced convection. If $\left(\rho_{\infty}-\rho\right)$ g is considered, along with $U_{\infty} \neq 0$, mixed convection is being analyzed with the effects of the natural and mixed convection adding each other for $\mathrm{U}_{\infty}>0$; and, otherwise, opposing each other. Natural convection is under consideration if $\left(\rho_{\infty}-\rho\right) g$ is not neglected and by imposing that either $\mathrm{U}_{\infty}=0$, or $\partial \mathrm{P} / \partial \mathrm{x}=0$.

The following method results from modifications imposed on the schemes of Shaw (1991), Hughes (1978) and Brooks \& Hughes (1982). Full developments and justifications can be found in the same cited references. One should note the "simple"-like procedure of the FVM (Patankar,
1980, Versteeg \& Malalasekera, 1995).

1. Evaluate estimates $\mathrm{u}^{*}$ and $\mathrm{v}^{*}$ for the velocity profile from (Brooks \& Hughes, 1982):

$$
\begin{gathered}
\int_{\Omega}\left(\rho \mathrm{u} \mathrm{W}_{\mathrm{i}} \frac{\partial \mathrm{N}_{\mathrm{j}}}{\partial \mathrm{x}}+\rho \mathrm{v} \mathrm{W}_{\mathrm{i}} \frac{\partial \mathrm{N}_{\mathrm{j}}}{\partial \mathrm{y}}+\mu \frac{\partial \mathrm{W}_{\mathrm{i}}}{\partial \mathrm{x}} \frac{\partial \mathrm{N}_{\mathrm{j}}}{\partial \mathrm{x}}+\mu \frac{\partial \mathrm{W}_{\mathrm{i}}}{\partial \mathrm{y}} \frac{\partial \mathrm{N}_{\mathrm{j}}}{\partial \mathrm{y}}\right) \mathrm{u}_{\mathrm{j}}^{*} \mathrm{~d} \Omega= \\
\int_{\Omega} \mathrm{W}_{\mathrm{i}}\left(-\frac{\partial \mathrm{p}}{\partial \mathrm{x}}+\left(\rho_{\infty}-\rho\right)\right) \mathrm{d} \Omega+\int_{\Gamma} \mathrm{W}_{\mathrm{i}}\left(\mu \frac{\partial \mathrm{u}}{\partial \mathrm{x}} \mathrm{n}_{\mathrm{x}}+\mu \frac{\partial \mathrm{u}}{\partial \mathrm{y}} \mathrm{n}_{\mathrm{y}}\right) \mathrm{d} \Gamma \\
\int_{\Omega}\left(\rho \mathrm{u} \mathrm{W}_{\mathrm{i}} \frac{\partial \mathrm{N}_{\mathrm{j}}}{\partial \mathrm{x}}+\rho \mathrm{v} \mathrm{W}_{\mathrm{i}} \frac{\partial \mathrm{N}_{\mathrm{j}}}{\partial \mathrm{y}}+\mu \frac{\partial \mathrm{W}_{\mathrm{i}}}{\partial \mathrm{x}} \frac{\partial \mathrm{N}_{\mathrm{j}}}{\partial \mathrm{x}}+\mu \frac{\partial \mathrm{W}_{\mathrm{i}}}{\partial \mathrm{y}} \frac{\partial \mathrm{N}_{\mathrm{j}}}{\partial \mathrm{y}}\right) \mathrm{v}_{\mathrm{j}}^{*} \mathrm{~d} \Omega= \\
\int_{\Omega}-\mathrm{W}_{\mathrm{i}} \frac{\partial \mathrm{p}}{\partial \mathrm{y}} \mathrm{d} \Omega+\int_{\Gamma} \mathrm{W}_{\mathrm{i}}\left(\mu \frac{\partial \mathrm{v}}{\partial \mathrm{x}} \mathrm{n}_{\mathrm{x}}+\mu \frac{\partial \mathrm{v}}{\partial \mathrm{y}} \mathrm{n}_{\mathrm{y}}\right) \mathrm{d} \Gamma
\end{gathered}
$$

Where $\Omega$ is the spatial domain and $\Gamma$ is the boundary; $\mathrm{n}_{\mathrm{x}}$ and $\mathrm{n}_{\mathrm{y}}$ are the outward normal unit vectors to each element boundary; $\mathrm{N}_{\mathrm{i}}$ represent usual linear shape functions; $\mathrm{W}$ refers to the streamline upwind weight used in the Petrov-Galerkin formulation as presented by Brooks \& Hughes (1982) and Zienkiewicz \& Taylor (1989, 1991). Initial values and best approximations for the velocity and pressure components are designated by u, v and p. From these values (always assumed to be known at the beginning of an iteration) and the above equations (5 and 6), one can obtain their starred $(*)$ or approximate values, $u_{j}{ }^{*}$ and $\mathrm{v}_{\mathrm{j}}{ }^{*}$.

2. Evaluate the pressure correction term, $\mathrm{p}_{\mathrm{j}}$, from (Shaw, 1991):

$-\int_{\Omega} \frac{\partial \mathrm{N}_{\mathrm{i}}}{\partial \mathrm{x}} \mathrm{N}_{\mathrm{j}} \mathrm{D}^{-1} \mathrm{Bd} \Omega \mathrm{p}_{\mathrm{j}}^{\prime}-\int_{\Omega} \frac{\partial \mathrm{N}_{\mathrm{i}}}{\partial \mathrm{y}} \mathrm{N}_{\mathrm{j}} \mathrm{D}^{-1} \mathrm{Bd} \Omega \mathrm{p}_{\mathrm{j}}^{\prime}=-\int_{\Omega} \mathrm{N}_{\mathrm{i}}\left(\frac{\partial \mathrm{u}^{\prime}}{\partial \mathrm{x}}+\frac{\partial \mathrm{v}^{*}}{\partial \mathrm{y}}\right) \mathrm{d} \Omega$

3. Evaluate the velocity correction terms, $\mathrm{u}_{\mathrm{j}}{ }^{\prime}$ and $\mathrm{v}_{\mathrm{j}}{ }^{\prime}$, from (Shaw, 1991):

$$
\begin{aligned}
& \int_{\Omega} \mathrm{N}_{\mathrm{i}} \mathrm{N}_{\mathrm{j}} \mathrm{u}_{\mathrm{j}}^{\prime} \mathrm{d} \Omega=\int_{\Omega} \mathrm{N}_{\mathrm{i}} \mathrm{N}_{\mathrm{j}} \mathrm{D}^{-1} \mathrm{Bp}_{\mathrm{j}}^{\prime} \mathrm{d} \Omega \\
& \int_{\Omega} \mathrm{N}_{\mathrm{i}} \mathrm{N}_{\mathrm{j}} \mathrm{v}_{\mathrm{j}}^{\prime} \mathrm{d} \Omega=\int_{\Omega} \mathrm{N}_{\mathrm{i}} \mathrm{N}_{\mathrm{j}} \mathrm{D}^{-1} \mathrm{Cp}_{\mathrm{j}}^{\prime} \mathrm{d} \Omega
\end{aligned}
$$

4. Form the corrected velocity correction terms, $u_{j}, v_{j}$ and $\mathrm{p}_{\mathrm{j}}$ from (Shaw, 1991):

$$
\mathrm{u}=\mathrm{u}^{*}+\mathrm{u}^{\prime} ; \mathrm{v}=\mathrm{v}^{*}+\mathrm{v}^{\prime} \text { and } \mathrm{p}=\mathrm{p}^{*}+\mathrm{p}^{\prime}
$$

5. Evaluate corrected $\mathrm{C}$ and $\mathrm{T}$ values from:

$$
\begin{aligned}
& \int_{\Omega}\left(\rho \mathrm{uN}_{\mathrm{N}} \frac{\partial \mathrm{N}_{\mathrm{j}}}{\partial \mathrm{x}}+\rho \mathrm{vN} \frac{\partial \mathrm{N}_{\mathrm{j}}}{\partial \mathrm{y}}+\mu \frac{\partial \mathrm{N}}{\partial \mathrm{x}} \frac{\partial \mathrm{N}_{\mathrm{j}}}{\partial \mathrm{x}}+\mu \frac{\partial \mathrm{N}}{\partial \mathrm{y}} \frac{\partial \mathrm{N}_{\mathrm{j}}}{\partial \mathrm{y}}\right) \mathrm{C}_{\mathrm{j}} \mathrm{d} \Omega=\int_{\Gamma} \mathrm{N}\left(\mu \frac{\partial \mathrm{C}}{\partial \mathrm{x}} \mathrm{n}_{\mathrm{x}}+\mu \frac{\partial \mathrm{C}}{\partial \mathrm{y}} \mathrm{n}_{\mathrm{y}}\right) \mathrm{d} \Gamma(12) \\
& \int_{\Omega}\left(\rho_{\mathrm{p}} \mathrm{uN} \frac{\partial \mathrm{N}_{\mathrm{j}}}{\partial \mathrm{x}}+\rho_{\mathrm{p}} \mathrm{vN} \frac{\partial \mathrm{N}_{\mathrm{j}}}{\partial \mathrm{y}}+\mu \frac{\partial \mathrm{N}}{\partial \mathrm{x}} \frac{\partial \mathrm{N}_{\mathrm{j}}}{\partial \mathrm{x}}+\mu \frac{\partial \mathrm{N}}{\partial \mathrm{y}} \frac{\partial \mathrm{N}_{\mathrm{j}}}{\partial \mathrm{y}}\right) \mathrm{T}_{\mathrm{j}} \mathrm{d} \Omega=\int_{\Gamma} \mathrm{N}\left(\mu \frac{\partial \Gamma}{\partial \mathrm{x}} \mathrm{n}_{\mathrm{x}}+\mu \frac{\partial \mathrm{T}}{\partial \mathrm{y}} \mathrm{n}_{\mathrm{y}}\right) \mathrm{d} \Gamma(13)
\end{aligned}
$$

6. If the convergence criteria are satisfied, stop; otherwise, return to step 1 .

\section{Finite element subdivision}

The region of interest was divided into two sub regions, 
as shown in Figure 2. The first and finer subdivided sub region, R1, could be characterized as having:

- Dimensions (cm): $0<\mathrm{x}<10$ and $0<\mathrm{y}<5$;

- Number of linear quadrilateral elements: 560;

- The discretizing lines were drawn in a direction closely perpendicular to the cylinder walls.

The second sub region, R2, was characterized by:

- Dimensions (cm): $10<x<15$ (if $\operatorname{Re}>60, x<20$ ) and $0<\mathrm{y}<5$;

- Number of elements: 100 .

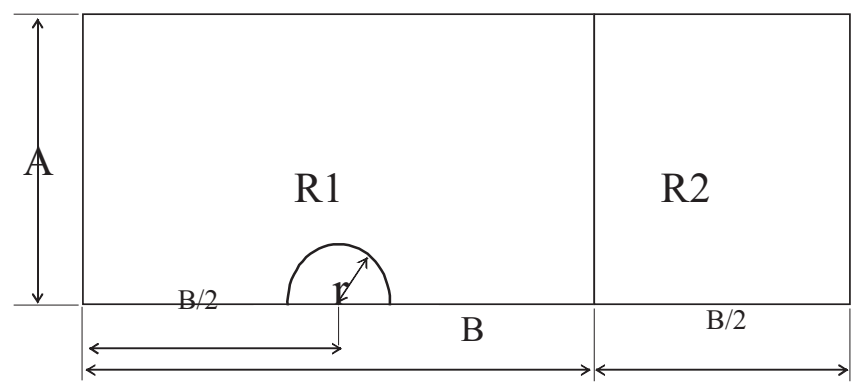

Figure 2. Subdivision of the region around the cylinder

\section{RESULTS AND DISCUSSION}

In this work the air physical properties were considered to be either constant or dependent on both temperature and concentration. When considered constant, the physical properties were evaluated at $\mathrm{T}_{\mathrm{R}}=\left(\mathrm{T}_{\mathrm{w}}+\mathrm{T}_{\infty}\right) / 2$ and $\mathrm{C}_{\mathrm{R}}=\left(\mathrm{C}_{\mathrm{w}}+\mathrm{C}_{\infty}\right) / 2$. In this work, Nusselt and Sherwood numbers are defined by $\mathrm{Nu}=\mathrm{hL} / \mathrm{k}_{\mathrm{T}}$ and $\mathrm{Sh}=\mathrm{h}_{\mathrm{m}} \mathrm{L} / \mathrm{D}$, where $\mathrm{L}$, the characteristic dimension, $\mathrm{D}$ is the cylinder diameter, $\mathrm{h}$ is the convective heat transfer coefficient, and $\mathrm{h}_{\mathrm{m}}$ the convective mass transfer coefficient.

Several test problems, extending from pure convection to diffusive-convective non-linear flow re-circulation problems, which included problems with Peclet numbers ranging from 0.1 to $\infty$ were tested. The results agreed with the ones available in the literature and they are not presented hereby for brevity. The following data on heat and mass transfer around cylinders are presented not only for the purpose of application of the model and analysis but also for further confirmation of the methodology.

Not all simulated conditions are shown. Figures $3 \mathrm{~A}$ and $3 \mathrm{~B}$ show part of the results when constant properties were assumed. In these figures, the results of this work were obtained by means of the FEM. These data refer to drying air at $80{ }^{\circ} \mathrm{C}$, at an absolute humidity of $0.0099 \mathrm{~kg}$ of vapor $\mathrm{kg}^{-1}$ of dry air; the cylinder surface temperature was kept at $25{ }^{\circ} \mathrm{C}$ and at saturation. Other simulated results involved lower drying air temperatures. As can be seen, the numerical results do not differ from empirically correlated data obtained from Hilpert (cited by Incropera \& Witt, 1992) and Churchill (1977). The numerical simulated results and Hilpert's and Churchill's data differ from
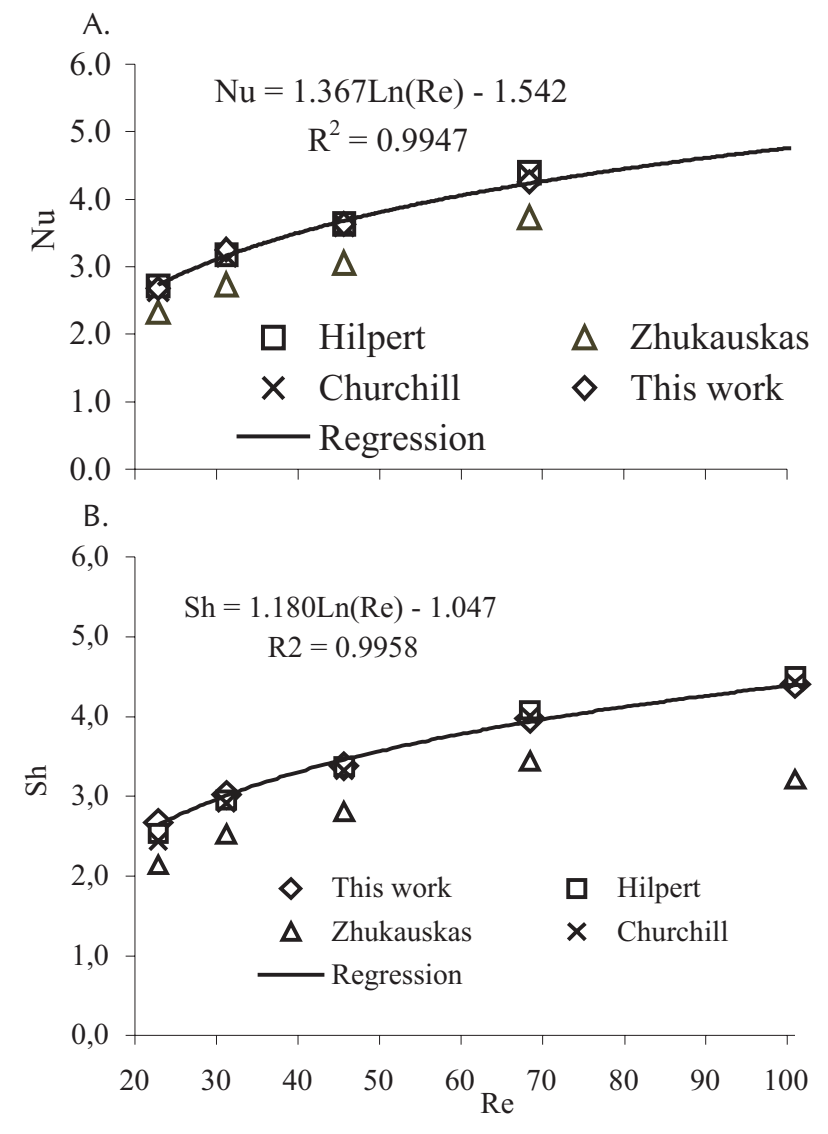

Figure 3. Nu versus $\operatorname{Re}(\mathrm{A})$ and $\mathrm{Sh}$ versus $\operatorname{Re}(\mathrm{B})$, for $\mathrm{T}_{w}=25^{\circ} \mathrm{C}$ and $\mathrm{T}_{\infty}=80^{\circ} \mathrm{C}$ (constant properties)
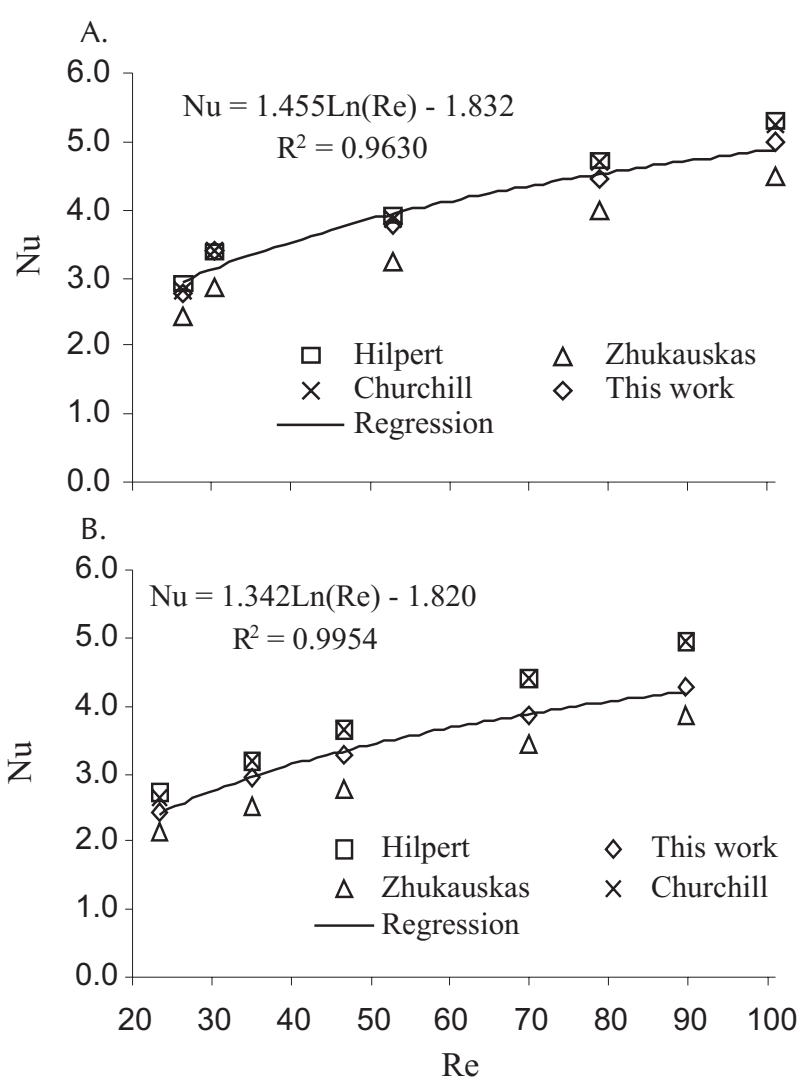

Figure 4. $\mathrm{Nu}$ versus $\mathrm{Re}$, for $\mathrm{T}_{w}=25{ }^{\circ} \mathrm{C}$ and $\mathrm{T}_{\infty}=30{ }^{\circ} \mathrm{C}(\mathrm{A})$ and $\mathrm{T}_{\infty}=80^{\circ} \mathrm{C}(\mathrm{B})$, with variable properties 
Zhukauskas' (cited by Incropera \& Witt, 1992) empirically correlated data. Simulated results for other temperatures revealed analogous results.

Figures 4 to 6 show the numerical results obtained by taking the thermodynamic and transport properties to be temperature and air humidity dependent. The simulation results are again compared against those obtained experimentally by Zhukauskas (1972) and Hilpert (1933) (both cited by Incropera \& Witt, 1992) and Churchill (1977).

The simulation data show that:

- At lower surface and air temperatures, the physical properties are practically constant and, consequently, the numerical results for Nusselt and Sherwood numbers approximate Hilpert's and Churchill's experimental data. On the other hand, the numerical results diverge somewhat from Hilpert and Churchill's and approximate Zhukauskas' results for higher $\mathrm{T}_{\infty}$ (Figures 4 and 5), due to the influence of the variable thermo physical properties on the boundary layer profiles.

- Figures 6A and 6B show that $\mathrm{Nu}$ and Sh increase as Reynolds numbers increase. These figures also show that, at temperatures higher than $40{ }^{\circ} \mathrm{C}, \mathrm{Nu}$ and $\mathrm{Sh}$ decrease significantly as the temperature increases, for
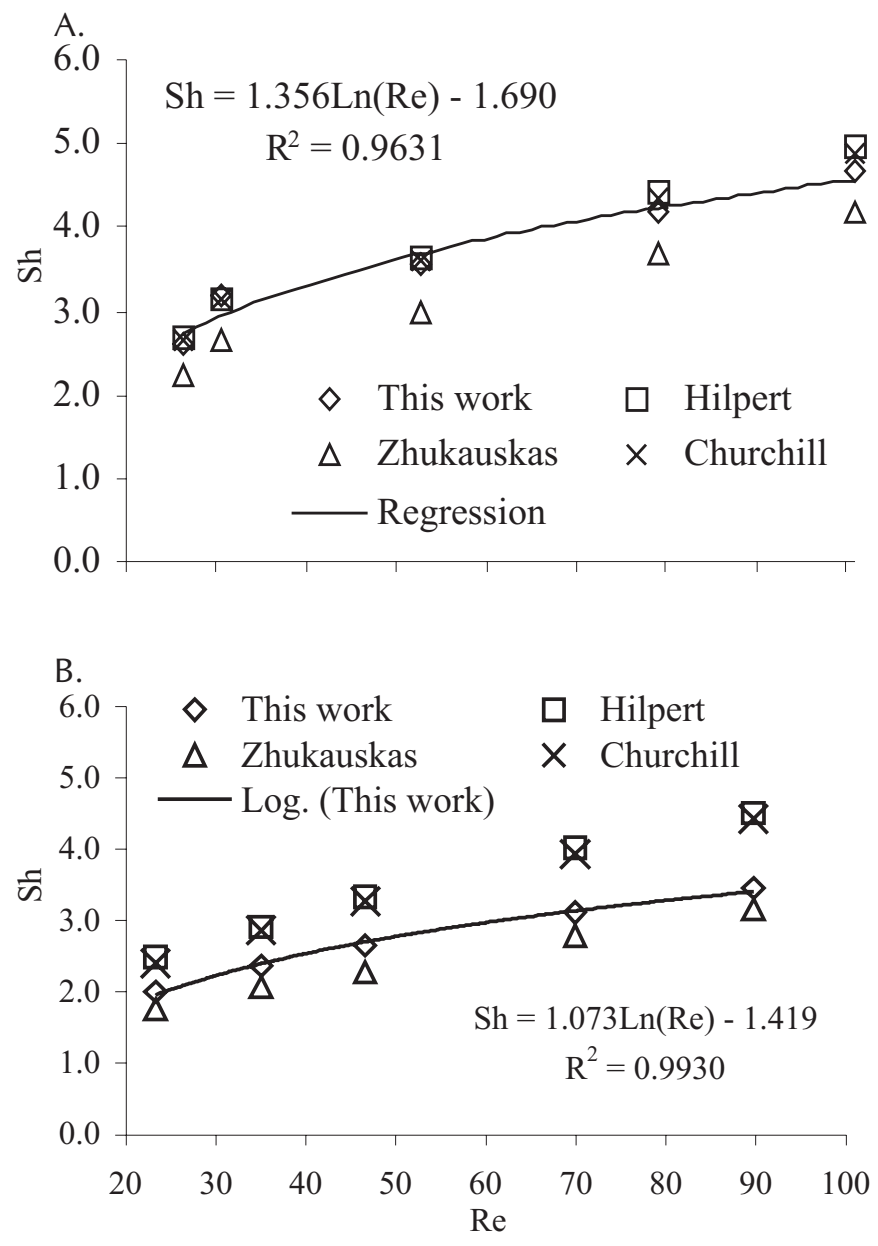

Figure 5. Sh versus $\operatorname{Re}$, for $\mathrm{T}_{w}=25^{\circ} \mathrm{C}$ and $\mathrm{T}_{\infty}=30^{\circ} \mathrm{C}(\mathrm{A})$ and $\mathrm{T}_{\infty}=80^{\circ} \mathrm{C}$ (B), with variable properties

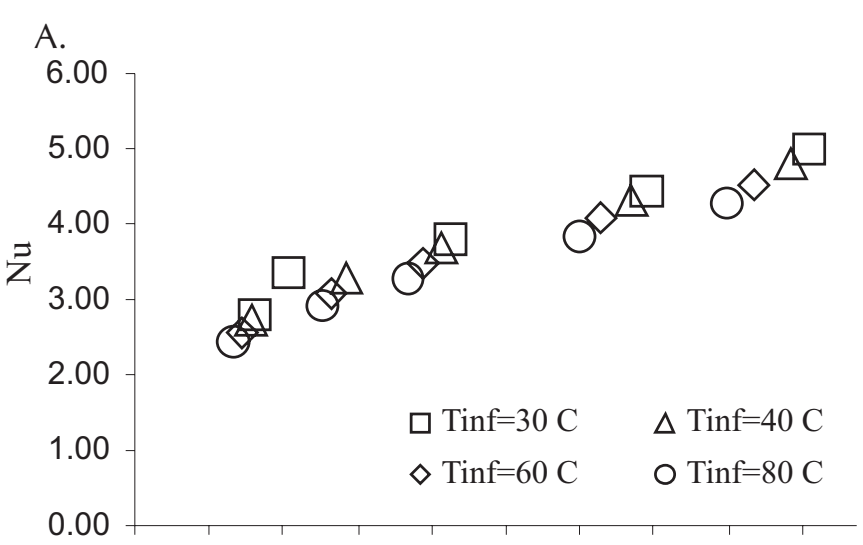

B.

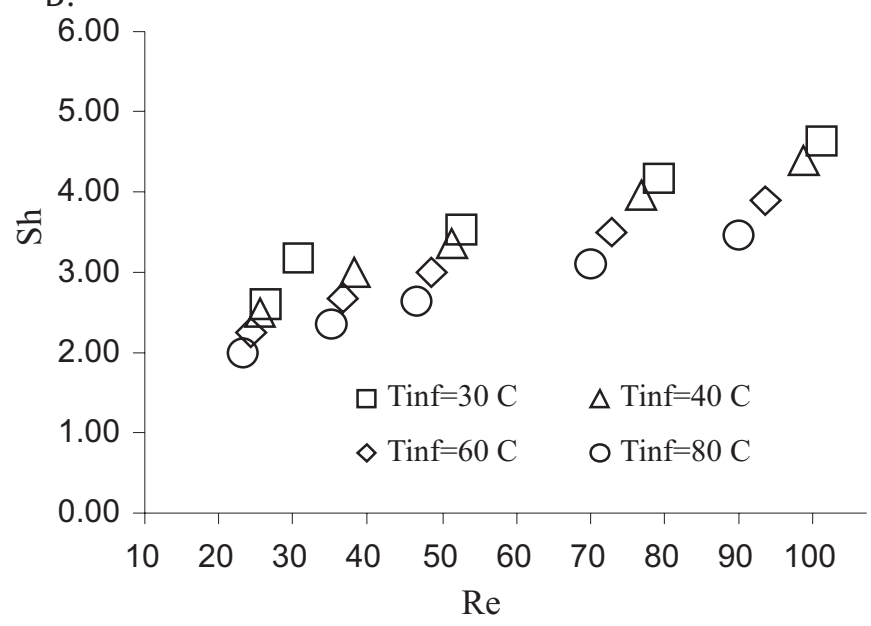

Figure 6. Simulated Nu versus $\operatorname{Re}(\mathrm{A})$ and $\mathrm{Sh}$ versus $\operatorname{Re}(\mathrm{B})$, for $\mathrm{T}_{w}=25^{\circ} \mathrm{C}$ and $\mathrm{T}_{\infty}=$ Tinf as a parameter

the same Re. This fact is, again, due to the variation of the thermodynamics and transport properties.

\section{CONCLUSIONS}

1. This paper presents a segregated finite element method that is proven to be useful to solve convection-diffusion problem. More specifically, the method was applied successfully to solve the problem of low and high-rate mass transfer along a biological horizontal cylinder so as to obtain the associated transport coefficients. With respect to this problem, the following conclusions were arrived at:

- The numerical results for Nusselt and Sherwood numbers agreed, within the associated experimental errors, with available empirical data.

- For higher accuracy of the numerical results, temperature and concentration dependent properties have to be considered in the models, when higher temperatures are at stake; otherwise appreciable difference between numerical and experimental results may result.

2. No effort has been made to simulate drying conditions involving wall convective mass fluxes. However, no 
restrictions were placed on the proposed methodology, which can be expanded, by simply forcing the associated boundary conditions to account for high rate mass transport processes.

\section{ACKNOWLEDGEMENTS}

The authors acknowledge the financial support granted by CNPq (National Council of Research and Technological Development) and Centro Universitário UNA.

\section{LITERATURE CITED}

Baker, A. J.; Chaffin, J. D.; Iannelli, J. S.; Roy, S. Finite elements for CDF - How does the theory compare? International Journal for Numerical Methods in Fluids. Chichester, v.31, p.345$358,1999$.

Balzano, A. Mosquito: An efficient finite difference scheme for numerical simulation of $2 \mathrm{D}$ advection. International Journal for Numerical Methods in Fluids. Chichester, v.31, p.481-496, 1999.

Brooker, D. B.; Bakker-Arkema, F. W.; Hall, C. W. Drying and storage of grains and oilseeds. New York: AVI Book, 1992. $464 p$.

Brooks, A. N.; Hughes, T. J. R. Streamline upwind Petrov-Galerkin formulation for convection-dominated flows with particular emphasis on the incompressible Navier-Stokes equations. Computer Methods in Applied Mechanics and Engineering, Austin, v.32, p.199-259, 1982.

Carey, G. F.; Pehlivanov, A. I.; Shen, Y.; Bose, A.; Wang, K. C. Least-squares finite elements for fluid flow and transport. International Journal for Numerical Methods in Fluids, Chichester, v.27, n.1, p.97-107, 1998.

Churchill, S. W. A comprehensive correlating equation for laminar, assisting, forced and free convection. AIChE Journal, Newark, v.23, n.1, p.10-16, 1977.

de Ville, A.; Smith, E. A. Airflow through beds of cereal grains. Applied Mathematical Modeling, Swansea, v.20, n.4, p.283289, 1996.

Fang, C. C.; Sheu, T.W.H.; Tsai, S. F. On a monotonic convection-diffusion scheme in adaptive meshes. Numerical Heat Transfer, Part B, Chicago, v.32, n.3, p.351-368, 1997.

Fortes, M. The diffusional method for convection-diffusion equations: finite element one-dimensional solutions. Numerical Methods in Thermal Problems, Swansea, v.10, n.1, p.57-68, 1997.

Fortes, M.; Ferreira, W. R. The one-dimensional transient diffusional method: finite element adaptive solutions to convectiondiffusion problems. International Journal of Thermal Sciences, Paris, v.38, n.9, p.780-796, 1999.

Fortes, M.; Okos, M. R. Drying theories: Their bases and limitations as applied to food and grain. In: Mujumdar A.S.(ed.). Advances in Drying. Washington, DC: Hemisphere Publishing Company, 1980. v.1, chap.3, p.119-154.

Fortes, M.; Okos, M. R. A non-equilibrium thermodynamics approach to transport phenomena in capillary porous media. Transactions of ASAE, St. Joseph, v.24, n.3, p.756-760, 1981.
Galan-Domingo, O.; Martinez-Vera, C. Use of an extended Kalman filter for the estimation of effective diffusion coefficients in cereal grains. Drying Technology, Quebec, v.14, n.7, p.17951813, 1996.

Gurgel, C. E. P.; Fortes, M. Evaluation of a streamline upwind method for convection dominated flows. In: Iberian Latin American Congress of Computational Mechanics, 15, 1994, Belo Horizonte. Anais..., Belo Horizonte: UFMG, 1994. p.274-283.

Hirsch, C. Numerical computation of internal and external flows - v.2; Computational methods for inviscid and viscous flows. Chichester: Wiley, 1988. 691p.

Hoffman, J. D. Numerical methods for engineers and scientists. New York: McGraw-Hill, 1992. 825p.

Hughes, T. J. R. A simple scheme for developing upwind finite elements. International Journal for Numerical Methods in Engineering, Swansea, v.12, n.1, p.1359-1365, 1978.

Incropera, F. P.; Witt, D. P. Fundamentos de transferência de calor e massa. Rio de Janeiro: Guanabara Koogan, 1992. 455p.

Keey, R. B. Drying: Principles and practice. Oxford: Pergamon Press, 1972. 358p.

Luikov, A. V. Application of irreversible thermodynamics methods to investigation of heat and mass transfer. International Journal Heat and Mass Transfer, Chicago, v.9, p.139-152, 1966.

Moukalled, F.; Darwish, M. A new family of streamline-based very-high-resolution schemes. Numerical Heat Transfer, Part B, Chicago, v.32, n.3, p.299-320, 1997.

Muthu, V. P.; Chattopadhyay, P. K. Prediction of heat of vaporization of moisture from cereal grains. A modeling approach. Drying Technology, Quebec, v.11, n.7, p.1855-1862, 1993.

Patankar, S. V. Numerical heat transfer and fluid flow. New York: Hemisphere, 1980. 197p.

Patel, M. K.; Markatos, N. C.; Cross, M. A critical evaluation of seven discretization schemes for convection-diffusion equations. International Journal for Numerical Methods in Fluids, Chichester, v.5, n.3, p.225-244, 1985.

Philip, J. R.; deVries, D. A. Moisture movement in porous material under temperature gradients. Transactions of the American Geophysical Union, Washington, v.38, n.2, p.222-231, 1957.

Schnipke, R. J.; Rice, J. G. A monotone streamline upwind finite element method for convection-dominated flows. Computer Methods in Applied Mechanics and Engineering, Austin, v.48, n.1, p. 313-327, 1985a.

Schnipke, R. J.; Rice, J. G. Examination of a new finite element method applied to convection heat transfer. Finite Element in Analysis and Design, Durham, v.1, n.3, p.227-239, 1985b.

Sengupta, T. K.; Nair, M. T. Upwind schemes and large eddy simulation. International Journal for Numerical Methods in Fluids, Chichester, v.31, n.5, p.879-889, 1999.

Shaw, C. T. Using a segregated finite element scheme to solve the incompressible Navier-Stokes equations. International Journal for Numerical Methods in Fluids, Chichester, v.12, n.1, p.8192, 1991.

Smith, E. A. Pressure and velocity of air during drying and storage of cereal grains. Transport in Porous Media, Haifa, v.23, n.2, p.197-218, 1996. 
Sotocinal,; Z.; Alikhani, S. A.; Raghavan, G. S. V. Heating/drying using particulate medium: a review. Part I. General and heat transfer parameters. Drying Technology, Quebec, v.15, n.2, p.441-459, 1997.

Taylor, C.; Hughes, T. G. Finite element programming of the Navier-Stokes equations. Swansea: Pineridge Press Ltd., 1981. 244p.

Tolaba, M. P.; Suarez, C.; Viollaz, P. Heats and entropies of sorption of cereal grains: a comparison between integral and differential quantities. Drying Technology, Quebec, v. 15, n.1, p.137-150, 1997.

Versteeg, H. K.; Malalasekera, W. An introduction to computational fluid dynamics - the finite volume method. London: Longman Scientific and Technical, 1995. 257p.
Zahed, A. H.; Epstein, N. Batch and continuous spouted bed drying of cereal grains: the thermal equilibrium model. The Canadian Journal of Chemical Engineering, Ottawa, v.70, n.5, p.945-953, 1992.

Zahed, A. H.; Epstein, N. On the diffusion mechanism during spouted bed drying of cereal grains. Drying Technology, Quebec, v.11, n.2, p.401-409, 1993.

Zienkiewicz, O. C.; Taylor, R. L. The finite element method. v.1. Basic formulations and linear problems. London: McGrawHill, 1989. 648p.

Zienkiewicz, O. C.; Taylor, R. L. The finite element method. v.2. Solid and fluid mechanics: dynamics and non-linearity. London: McGraw-Hill, 1991. 807p. 